\title{
Hematological and biochemical profile of BALB/c nude and C57BL/6 SCID female mice after ovarian xenograft
}

\author{
DENILSA P. FERNANDES, MURIEL M.L. PIMENTEL, FERNANDA A. DOS SANTOS, \\ ÉRIKA A. PRAXEDES, PARMÊNEDES D. DE BRITO, MIKAEL A. LIMA, IVANA \\ C.N.G. LELIS, MICHELLY F. DE MACEDO and MARCELO B. BEZERRA
}

\begin{abstract}
Laboratório de Transplantes Gonadais e Produção In Vitro de Embriões/LTG-PIVE, Departamento de Ciências Animais, Universidade Federal Rural do Semi-Árido/UFERSA, Avenida Francisco Mota, 572, 59625-900 Mossoró, RN, Brazil
\end{abstract}

Manuscript received on October 31, 2017; accepted for publication on July 19, 2018

\begin{abstract}
Hematological and biochemical profile studies help to evaluate functional changes of animals used in experiments. The aim of this study was to determine the hematological and biochemical profile of immunosuppressed BALB/c nude and C57BL/6 SCID mice after bovine ovarian xenotransplantation. Therefore, a total of 74 female mice were divided into four groups: non-xenotransplanted animals, xenotransplanted animals, xenotransplanted animals treated with eCG and xenotransplanted animals treated with FSH + LH. After anesthesia, blood samples were collected and hematologic and biochemical values were evaluated. The results showed no significant differences $(p \leq 0.05)$ for hematological parameters between the control group and the treatment groups of both strains. However, considering the biochemical profile, it was observed an increase of AST concentrations $(\mathrm{p} \leq 0.05)$ in both strains and a decrease of ALT concentrations $(p \leq 0.05)$ only in C57BL/6 SCID strain of the groups subjected to hormonal treatment compared with those non subjected. Additionally, the values of the renal enzymes, urea and creatinine, did not differ $(\mathrm{p} \leq 0.05)$ between the groups. Our findings suggest that the xenotransplantation procedure as well as the hormonal dosages had no significant effect on the well-being of the animals considering the evaluated hematological and biochemical profile.
\end{abstract}

Key words: biochemistry, hematology, immunosuppressed, Mus musculus.

\section{INTRODUCTION}

Ovarian xenotransplantation is used as an alternative method to maintain ovarian functions such as hormone release, ovulation, and fertility through the development of ovarian tissue of a particular species in a specific site of another species. Therefore, the technique is valuable for patients submitted to

Correspondence to: Denilsa Pires Fernandes

E-mail: denilsas2@hotmail.com chemotherapy or irradiation therapy that had their reproductive functions compromised, animals with economical and ecological relevance and also for preservation of endangered species (Kikuchi et al. 2011, Pimentel et al. 2017). Considering that bovine slaughterhouse ovaries are abundantly available and that the species has similarities with humans in reproductive physiology, bovine ovarian xenotransplantation is a promise procedure (Langbeen et al. 2016). 
To carry out the ovarian xenotransplantation technique, immunodeficient mice, such as the athymic nude and SCID (Severe Combined Immunodeficient) strains, can be used as models of choice to receive the exogenous tissue (Meng et al. 2014, Noorani et al. 2015, Dittrich et al. 2015, Dos Santos et al. 2016) since the chances of biochemical graft rejection decrease due to their low or lack of immune response (Aubard 2003). Therefore, it is important to evaluate the most appropriate experimental model for bovine ovarian xenotransplantation.

Considering that the hematological and biochemical parameters help to assess possible organism pathologies or functional changes, the analysis of these parameter profiles can be used to evaluate the ovarian xenotransplantation technique in relation to damages caused in the function of the recipient site and the homeostasis of the animal during the experimental period (Pimentel et al. 2017). Currently, data on hematological and biochemical analysis that can be correlated to this study are scarce in the literature. Besides, because physiological parameters may vary according to age, sex, strain, handling, environmental conditions, blood collection method, geographic factors, and other intraspecies factors (Santos et al. 2016) it is extremely important that each laboratory should determine its own reference ranges and standardize the conditions that the animals are subjected to in order to evaluate the possible influences in the procedure tested (Matida et al. 2015).

Therefore, this study aims to determine the hematological and biochemical profile of two immunosuppressed female mice (Mus musculus) strains (BALB/c nude and C57BL/6 SCID) after bovine ovarian xenotransplantation.

\section{MATERIALS AND METHODS}

All procedures were carried out in accordance with the principles established by the Colégio Brasileiro de Experimentação Animal (COBEA) (1988) and approved by the Committee of Ethics and Animal Welfare (CEBEA) of the Universidade Federal Rural do Semiá-rido (UFERSA), under the protocol 23091.003217/2014-17.

\section{ANIMALS AND EXPERIMENTAL DESIGN}

A total of 74 immunosuppressed adult female mice (BALB/c nude $(\mathrm{n}=40)$ and C57BL/6 SCID $(\mathrm{n}=$ 34)) of age 2-3 months old, with the body weight range from 20-35 g, were kept in mini-islolator cages $(20 \times 15 \times 13 \mathrm{~cm})$ in groups of five animals per cage, with positive pressure at $22^{\circ} \mathrm{C}$, light/ dark cycle of 14/10 hours and free access to proper water and food (Nuvilab CR1, Quimtia SA). All the animals were kept under germfree conditions. The animals were not fasted in this study.

The mice were divided into four groups: Control Group $(\mathrm{n}=20)$, non-xenotransplanted animals; Group $1(\mathrm{n}=18)$, xenotransplanted animals not treated with hormone); Group $2(\mathrm{n}=18)$, xenotransplanted animals treated with eCG (Equine Chorionic Gonadotrophin; Novormon $\left.{ }^{\circledR}\right)$; and Group $3(\mathrm{n}=18)$, xenotransplanted animals treated with FSH + LH (Follicle Stimulating Hormone + Luteinizing Hormone Pluset ${ }^{\circledR}$ ). The application of gonadotrophins in the recipient animals was perform as a strategy for improving the development of the xenotransplanted ovarian tissue.

\section{SURGICAL PROCEDURE}

Before the surgical procedure the mice were anesthetized intraperitoneally with 2,2,2-tribromoethanol (Avertin 2.5\%, SigmaAldrich, São Paulo, Brazil) according with their body weight (C57BL6 SCID with $18 \mathrm{ml} / \mathrm{kg}$; BALB/c nude with $20 \mathrm{ml} / \mathrm{kg}$ ). For the surgical procedure, five fragments of, approximately, 1 $\mathrm{mm}^{3}$ were recovered from heifer ovarian cortex and placed on the left renal capsule of each recipient animal. In order to avoid their endogenous hormonal influence on the new transplanted tissue, the animals 
were initially submitted to bilateral ovariectomy. Mice were allowed to recover on a warmed plate and were sedated with ketoprofen (Laboratório Cristália, Brasil; $0.8 \mathrm{mg} / \mathrm{kg}$ ) intraperitoneally every 12 hours for 2 days.

\section{HORMONE TREATMENT}

The transplanted mice were divided into three groups according to whether or not they had hormonal treatment, namely: Group 1 (G1): mice not treated with hormone $(\mathrm{n}=10 \mathrm{BALB} / \mathrm{c}$ nude; $\mathrm{n}$ $=8 \mathrm{C} 57 \mathrm{BL} / 6 \mathrm{SCID})$; Group 2 (G2): mice treated with $10 \mathrm{IU}$ of eCG $\left(\right.$ Novormon $\left.^{\circledR}\right)(\mathrm{n}=10 \mathrm{BALB} / \mathrm{c}$ nude; $\mathrm{n}=8$ C57BL/6 SCID); Group 3 (G3): mice treated with $10 \mathrm{IU}$ of FSH $+\mathrm{LH}\left(\right.$ Pluset $\left.^{\circledR}\right)(\mathrm{n}=10$ $\mathrm{BALB} / \mathrm{c}$ nude; $\mathrm{n}=8 \mathrm{C} 57 \mathrm{BL} / 6 \mathrm{SCID})$.

The hormones doses of eCG and FSH $+\mathrm{LH}$ were applied every 12 hours on days 58 and 59 after surgery, 48 hours before the blood collection.

\section{BLOOD COLLECTION}

Sixty days after transplantation, blood samples were collected by cardiac puncture according to Hoff (2000), using EDTA (Ethylenediamine Tetra-Acetic Acid) $10 \%$ as anticoagulant after anesthetizing the mice with 2,2,2 tribromoethanol $2.5 \%$. Approximately, 1-1,5 $\mathrm{ml}$ of blood were collected per animal, placed on previously identified $2 \mathrm{~mL}$ microtubes and used for hematological and biochemical analyzes.

\section{ASSESSMENT OF HEMATOLOGICAL PARAMETER}

The hematological analyses were performed using an automatic veterinary haematological analyzer (ABC VET, HORIBA $\left.{ }^{\circledR}, \mathrm{UK}\right)$ to assess the complete blood count, namely: red blood cells (RBC), hemoglobin, hematocrit, mean corpuscular volume (MCV), mean corpuscular hemoglobin concentration (MCHC), total and differential leukocyte and platelet counts. Differential leukocyte counts were performed on blood smears stained with a commercial agent (Panótico Rápido LB, Laborclin, São Paulo, Brazil) and analyzed under light microscopy, counting 100 cells and establishing the relative and absolute leukocyte counts.

\section{ASSESSMENT OF BIOCHEMICAL PARAMETERS}

For this purpose the blood samples were kept at room temperature in identified microtubes and centrifuged at $1200 \mathrm{~g}$ for 10 minutes to obtain the plasma. All the biochemical analysis were validated and performed via spectrophotometry in the semiautomatic biochemical analyzer (Bioplus-2000), using commercial kits (Vida Biotecnologia Ltda - BRASIL). Components such as urea, creatinine, aspartate aminotransferase (AST), alanine aminotransferase (ALT) and alkaline phosphatase (FAL) were determined.

\section{STATISTICAL METHODS}

The biochemical and hematological data were examined by the Kruskal-Wallis test followed by the Student-Newman-Keuls test to compare means and standard deviations. The results were considered statistically significant according to $\mathrm{p} \leq 0.05$.

\section{RESULTS}

Hematological parameters of the BALB/c nude and C57BL/6 SCID mice are shown in Tables I and II, respectively. No difference $(\mathrm{p} \leq 0.05)$ was found considering the hematological parameters of the two strains evaluated. For differential leukocyte count it was determined a relative number of different leukocyte populations (lymphocytes, neutrophils, eosinophils, basophils and monocytes). In both strains it was not found basophils.

Additionally, the biochemical analysis of respectively BALB/c nude and C57BL/6 SCID female mice are presented in Tables III and IV. A variation was found in liver enzymes levels such as AST and ALT between the groups evaluated.

The results presented in the tables are expressed in Mean \pm Standard Deviation. 


\section{DISCUSSION}

In this study, the results of the control group (nonxenotransplanted mice) were used as reference values for a better analysis of the serum levels of each parameter evaluated in the experimental groups.

It is important to use data determined by the laboratory as its own reference ranges to obtain a better interpretation of the analyses performed (Matida et al. 2015), since the physiological parameters of experimental animals of each laboratory may vary as a function of age, strain, environmental conditions they are subjected to, diet, handling, and even intraspecies variability (Santos et al. 2016). However, it is advised not to use only these values to indicate possible effects of the procedure applied in the study or consider them only as normal or abnormal (Florence et al. 2010).

The method of blood collection used in this study is considered fast and reliable, causing little stress to the animal in relation to the large volume of blood obtained (Doeing et al. 2003). Furthermore, the heart blood collection method has been reported to provide more consistent results with low deviation (Hoggatt et al. 2016).

The hematological evaluation results of both strains showed no difference $(\mathrm{p} \leq 0.05)$ among all parameters analyzed, suggesting that the surgical procedure, anesthesia and the hormonal protocol had no effect on the hematological parameters of the animals. In addition, RBC, Hematocrit, Hemoglobin, $\mathrm{MCV}$ and $\mathrm{CHCM}$ values of both strains are within the normal range reported by Bolliger and Everds (2010) for mice in general, taking into consideration that the authors provided no information on the strain or sex used for determining the reference values. In contrast to what was observed in the erythrogram, the total leukocyte count in this study was lower than the reference cited above established for common mice.

It is important to consider that the both strains used in this study have their immune cells compromised, in this respect, the nude animals are athymic, consequently the $\mathrm{T}$ lymphocytes are immature and nonfunctional and the SCID mice have $\mathrm{B}$ and $\mathrm{T}$ lymphocyte deficiency. However, it is not conclusive that the difference between these genetically modified mice and the common mice is significant or even has some relation with the immunodeficiency.

Considering the leukocyte differential count, the monocytes, eosinophils and basophils had the lowest values in both strains (Tables I and II), showing no difference $(\mathrm{p} \leq 0.05)$ between the groups. The relevance of the decrease shown in these blood cells is difficult to determine, since they are normally present in small amounts (Florence et al. 2010). The same authors indicates that in mice the lymphocytes comprise the highest percentage (70-80\%) of the leukocyte differential count, followed by neutrophils (20-30\%), which is consistent with the results obtained in this study.

Blood biochemical profiles reflect the physiological conditions of the animal and constitute a diagnostic tool of great interest (González 2009). Thus, in order to analyze whether the surgical procedure influenced the function of the transplant recipient organ, the renal biochemical profile was evaluated with basis on the urea and creatinine measurements. Moreover, to evaluate the general metabolism status of the animals, the biochemical profile was evaluated with basis on the values of liver enzymes such as ALT, AST and FAL.

The enzymatic profile is one of the blood parameters with the greatest variability; in that case it is important to perform a more accurate evaluation and an appropriate interpretation of the biochemical profile (González et al. 2001).

There was significant difference $(\mathrm{p} \leq 0.05)$ for the AST levels from BALB/c nude mice of groups G2 and G3, which had higher values than the other groups (Table III). This difference detected in these groups treated with hormone is not sufficient to determine a liver injury, since neither physical symptoms equivalent to liver 
TABLE I

Hematological parameters of BALB/c nude female mice.

\begin{tabular}{cccccc}
\hline Parameter & Unit & Control & G1 & G2 & G3 \\
\hline RBC & \multicolumn{7}{c}{ ERYTHROGRAM } & $7.16 \pm 2.16$ & $7.20 \pm 1.50$ & $6.97 \pm 2.44$ \\
Hematocrit & $10^{6} / \mathrm{mm}^{3}$ & $7.64 \pm 2.19$ & $37.50 \pm 3.14$ & $39.80 \pm 2.74$ & $38.80 \pm 2.86$ \\
Hemoglobin & $\%$ & $38.35 \pm 3.10$ & $11.96 \pm 1.23$ & $12.83 \pm 0.90$ & $12.45 \pm 1.03$ \\
MCV & $\mathrm{g} / \mathrm{dL}$ & $12.35 \pm 1.29$ & $57.83 \pm 14.46$ & $61.67 \pm 21.11$ \\
MCHC & $\mathrm{fm}^{3}$ & $53.93 \pm 14.51$ & $45.79 \pm 23.08$ & $32.22 \pm 0.57$ & $32.07 \pm 0.93$ \\
\hline Total leukocytes & $10^{3} / \mathrm{mm}^{3}$ & $1.53 \pm 0.47$ & $1.32 \pm 0.5$ & $1.60 \pm 0.73$ & $1.43 \pm 0.42$ \\
Lymphocytes & $\%$ & $69.35 \pm 14.82$ & $71.90 \pm 2.38$ & $72.50 \pm 2.12$ & $72.60 \pm 2.88$ \\
Neutrophils & $\%$ & $21.95 \pm 3.41$ & $22.10 \pm 2.64$ & $21.40 \pm 2.55$ & $22.10 \pm 1.85$ \\
Eosinophils & $\%$ & $2.40 \pm 1.70$ & $2.40 \pm 1.35$ & $2.30 \pm 1.34$ & $2.20 \pm 1.55$ \\
Basophils & $\%$ & 0.00 & 0.00 & 0.00 & 0.00 \\
Monocytes & $\%$ & $3.30 \pm 1.22$ & $3.30 \pm 0.95$ & $3.50 \pm 0.85$ & $3.10 \pm 0.99$ \\
\hline Platelets & $10^{3} / \mathrm{mm}^{3}$ & $450.70 \pm 14.26$ & $428.10 \pm 73.25$ & $450.60 \pm 72.07$ & $408.20 \pm 55.10$ \\
\hline
\end{tabular}

Kruskal-Wallis test $(\mathrm{p} \leq 0.05)$. G1: xenotransplanted mice not treated with hormone; G2: xenotransplanted mice treated with eCG; G3: xenotransplanted mice treated with FSH + LH. RBC: red blood cells; MCV: mean corpuscular volume; MCHC: mean corpuscular hemoglobin concentration.

TABLE II

Hematological parameters of C57BL/6 SCID female mice.

\begin{tabular}{|c|c|c|c|c|c|}
\hline Parameter & Unit & Control & G1 & G2 & G3 \\
\hline \multicolumn{6}{|c|}{ ERYTHROGRAM } \\
\hline $\mathrm{RBC}$ & $10^{6} / \mathrm{mm}^{3}$ & $7.48 \pm 2.73$ & $7.14 \pm 1.39$ & $7.83 \pm 1.49$ & $7.96 \pm 2.52$ \\
\hline Hematocrit & $\%$ & $39.95 \pm 3.35$ & $39.50 \pm 1.93$ & $38.13 \pm 2.90$ & $39.38 \pm 1.92$ \\
\hline Hemoglobin & $\mathrm{g} / \mathrm{dL}$ & $13.15 \pm 0.88$ & $12.49 \pm 0.52$ & $12.13 \pm 0.83$ & $12.88 \pm 0.64$ \\
\hline $\mathrm{MCV}$ & $\mathrm{fm}^{3}$ & $61.17 \pm 26.84$ & $59.04 \pm 20.62$ & $52.13 \pm 7.98$ & $54.08 \pm 17.94$ \\
\hline $\mathrm{MCHC}$ & $\%$ & $33.11 \pm 1.45$ & $33.22 \pm 0.96$ & $31.67 \pm 2.07$ & $32.41 \pm 0.66$ \\
\hline \multicolumn{6}{|c|}{ LEUKOGRAM } \\
\hline Total leukocytes & $10^{3} / \mathrm{mm}^{3}$ & $0.92 \pm 0.32$ & $1.1 \pm 0.18$ & $0.96 \pm 0.21$ & $0.95 \pm 0.23$ \\
\hline Lymphocytes & $\%$ & $71.65 \pm 2.91$ & $69.75 \pm 5.97$ & $71.50 \pm 3.42$ & $71.38 \pm 5.97$ \\
\hline Neutrophils & $\%$ & $21.70 \pm 2.36$ & $22.50 \pm 2.83$ & $22.00 \pm 1.41$ & $21.88 \pm 1.89$ \\
\hline Eosinophils & $\%$ & $3.10 \pm 1.80$ & $3.25 \pm 1.58$ & $3.00 \pm 1.69$ & $2.88 \pm 1.25$ \\
\hline Basophils & $\%$ & 0.00 & 0.00 & 0.00 & 0.00 \\
\hline Monocytes & $\%$ & $3.55 \pm 1.19$ & $4.00 \pm 1.93$ & $3.63 \pm 1.06$ & $3.75 \pm 1.83$ \\
\hline \multicolumn{6}{|c|}{ PLATELET COUNT } \\
\hline Platelets & $10^{3} / \mathrm{mm}^{3}$ & $418.25 \pm 78.31$ & $386.38 \pm 69.36$ & $411.88 \pm 48.88$ & $392.88 \pm 77.58$ \\
\hline
\end{tabular}

Kruskal-Wallis test $(\mathrm{p} \leq 0.05)$. G1: xenotransplanted mice not treated with hormone; G2: xenotransplanted mice treated with eCG; G3: xenotransplanted mice treated with FSH + LH. RBC: red blood cells; MCV: mean corpuscular volume; MCHC: mean corpuscular hemoglobin concentration. 
disease in the animals nor changes in the other biochemical values were detected. Furthermore, the ALT enzyme concentration is considered to be a better indicator for assessing liver cell integrity than AST (Xu et al. 2015), probably because it is predominantly found in this organ, specifically in hepatocyte mitochondria, and for having a longer half-life (Botros and Sikaris 2013). Additionally, besides being a marker of liver diseases, ALT is also considered as an indicator of general health (Kim et al. 2008). Thus, it is believed that significant increases in AST values alone are not usually due to liver injury (Botros and Sikaris 2013). This increase may have been caused by muscle stress (Melo et al. 2012), as these animals were subjected to hormone injections prior to blood collection, but it does not necessarily indicate some impairment in the homeostasis of the animals.

The C57BL/6 SCID groups treated with hormone showed a significant decrease in the ALT plasma level (Table IV), which was possibly influenced by the hormone administration. It has been found that exogenous female sex hormone (estrogen) tends to decrease ALT levels (Kim et al. 2008, Xin et al. 2015), but we found no study correlating this fact with the hormones used in this study. Despite this difference, the results suggest no hepatic damage, and the animals evaluated remained healthy throughout the experimental period. The data presented in Table IV show that the AST levels of the control group differed statistically $(\mathrm{p} \leq 0.05)$ from the others, with an increase of this enzyme levels. It is possible that the surgical procedure performed in the experimental groups (G1, G2 and G3) increased the stress level, which may have altered this biochemical marker. However, this variation is not enough to assume liver damage. Overall, the parameters of the hepatic biochemical profile ALT, AST, and FAL were within the range reported for common mice in literature (Campbell 2007).
The values referring to the renal function urea and creatinine of both strains were not different $(p \leq 0.05)$ between the groups analyzed. The level of creatinine found in this study was similar to levels reported for common mice (Campbell 2007). However, the urea concentration was high. A possible explanation for this result may be the high protein value diet which the animals were submitted, increasing the level of this metabolite over the higher nitrogen metabolism, therefore, not linking this difference with renal diseases (Thrall 2007). Thus, the data suggest that there was no renal damage in the animals during the experiment.

The data presented in the study establish laboratory reference values, but not necessarily reflect the normal or abnormal condition of the animal strains, reinforcing the need for each laboratory to determine its own reference values since studies differ in methods used during the blood analysis, which directly influences the results (Horowitz 2008).

The International Federation of Clinical Chemistry (IFCC) recommends a minimum number of 120 individual samples of healthy experimental animals for reference intervals. Since it is an expensive and laborious method, determining the reference range of biochemical and hematological parameters is still a challenge among researchers. For this reason, Horowitz (2008) proposed that if several laboratories using the same methodology and collecting 20 samples each it would be possible to pool the data to obtain the 120 samples needed to establish more reliable reference intervals. Thus, the findings presented in this study contribute to establishing reference intervals for physiological parameters of immunodeficient mice of the BALB/c nude and C57BL/6 SCID strains, plus, considering the lack of data in literature about this matter.

Additionally, studies report their own reference values for physiological parameters (biochemical and hematological) of isogenic BALB/c and C57BL/6 mice (Almeida et al. 2008, 
TABLE III

Biochemical parameters of BALB/c nude female mice.

\begin{tabular}{cccccc}
\hline Parameter & Unit & Control & G1 & G2 & G3 \\
\hline ALT & $\mathrm{U} / \mathrm{L}$ & $143.26 \pm 44.71$ & $145.40 \pm 44.66$ & $151.03 \pm 45.70$ & $155.91 \pm 72.67$ \\
AST & $\mathrm{U} / \mathrm{L}$ & $126.95 \pm 20.09^{\mathrm{b}}$ & $135.80 \pm 21.96^{\mathrm{b}}$ & $156.10 \pm 30.39^{\mathrm{a}}$ & $162.10 \pm 21.11^{\mathrm{a}}$ \\
FAL & $\mathrm{U} / \mathrm{L}$ & $218.07 \pm 69.97$ & $232.56 \pm 65.33$ & $213.96 \pm 64.12$ & $194.31 \pm 40.95$ \\
Creatinine & $\mathrm{mg} / \mathrm{dl}$ & $0.48 \pm 0.10$ & $0.50 \pm 0.09$ & $0.48 \pm 0.06$ & $0.46 \pm 0.13$ \\
Urea & $\mathrm{mg} / \mathrm{dl}$ & $60.70 \pm 13.17$ & $61.45 \pm 13.73$ & $63.89 \pm 8.43$ & $52.25 \pm 16.38$ \\
\hline
\end{tabular}

${ }^{\mathrm{a}, \mathrm{b}}$ : different letters on the same row indicate significantly different values. Kruskal-Wallis test ( $\left.\mathrm{p} \leq 0.05\right)$. G1: xenotransplanted mice not treated with hormone; G2: xenotransplanted mice treated with eCG; G3: xenotransplanted mice treated with FSH + LH. ALT: alanine aminotransferase; AST: aspartate aminotransferase; FAL: alkaline phosphatase.

TABLE IV

Biochemical parameters of C57BL/6 SCID female mice.

\begin{tabular}{cccccc}
\hline Parameter & Unit & Control & G1 & G2 & G3 \\
\hline ALT & $\mathrm{U} / \mathrm{L}$ & $140.20 \pm 28.79^{\mathrm{a}}$ & $96.88 \pm 38.37^{\mathrm{a}}$ & $82.88 \pm 35.01^{\mathrm{b}}$ & $82.38 \pm 43.42^{\mathrm{b}}$ \\
AST & $\mathrm{U} / \mathrm{L}$ & $73.45 \pm 37.99^{\mathrm{b}}$ & $122.50 \pm 13.69^{\mathrm{a}}$ & $137.13 \pm 49.01^{\mathrm{a}}$ & $146.38 \pm 51.96^{\mathrm{a}}$ \\
FAL & $\mathrm{U} / \mathrm{L}$ & $165.50 \pm 24.53$ & $153.21 \pm 18.18$ & $132.38 \pm 65.30$ & $136.00 \pm 49.35$ \\
Creatinine & $\mathrm{mg} / \mathrm{dl}$ & $0.40 \pm 0.06$ & $0.35 \pm 0.08$ & $0.34 \pm 0.05$ & $0.34 \pm 0.11$ \\
Urea & $\mathrm{mg} / \mathrm{dl}$ & $60.40 \pm 8.72$ & $56.00 \pm 6.97$ & $55.88 \pm 4.85$ & $60.25 \pm 8.51$ \\
\hline
\end{tabular}

a, b: different letters on the same row indicate significantly different values. Kruskal-Wallis test ( $\mathrm{p} \leq 0.05)$. G1: xenotransplanted mice not treated with hormone; G2: xenotransplanted mice treated with eCG; G3: xenotransplanted mice treated with FSH + LH. ALT: alanine aminotransferase; AST: aspartate aminotransferase; FAL: alkaline phosphatase.

Spinelli et al. 2012, 2014, Santos et al. 2016). These parameters are subject to variations according to some characteristics of the species such as sex, strain, age, health conditions and other intrinsic and extrinsic factors (Almeida et al. 2008). These variables should be evaluated when comparing results from different studies, since isogenic animals may differ from one laboratory to another (Damy et al. 2010). Moreover, the lack of data in the literature reporting the hematological profile of immunosuppressed mice made it difficult to compare the results presented in this study with other studies.

In summary, as that the only difference showed in the results, by liver enzymes levels, did not demonstrate hepatic damage, the biochemical and hematological evaluation performed in this study indicate that the xenotransplantation procedure and the hormonal treatment had no significantly effect on the well-being of the mice considering the blood, liver and renal evaluation. Therefore, the data obtained are relevant for the validation of several studies, as well as for the establishment of standard values that can help indicate unusual serum biochemical or hematologic values. Moreover, considering the lack of bibliographic data addressing the hematological and biochemical profile of the BALB/c nude and C57BL/6 SCID mice strain, the results from this study can be used as a parameter for future researches in order to investigate the general health of the experimental models above mentioned.

\section{REFERENCES}

ALMEIDA SA, FALEIROS ACG, TEIXEIRA DNS, COTA UA AND CHICA JEL. 2008. Valores de referência de parâmetros bioquímicos no sangue de duas linhagens de camundongos. J Bras Patol Med Lab 44: 429-432.

AUBARD Y. 2003. Ovarian tissue xenografting. Eur J Obstet Gynecol Reprod Biol 108: 14-18.

BOLLIGER AP AND EVERDS NE. 2010. Hematology of Laboratory Animals. In: Weiss DJ and Wardrop KJ (Eds), Schalm's Veterinary Hematology. Ames: Wiley-Blackwell, p. 856. 
BOTROS M AND SIKARIS KA. 2013. The de ritis ratio: the test of time. Clin Biochem Ver 34: 117-30.

CAMPBELL TW. 2007. Hematologia de mamíferos: animais de laboratório e espécies variadas. In: Thrall MA (Ed), Hematologia e Bioquímica Clínica Veterinária. São Paulo: Roca, p. 201-214.

DAMY SB, CAMARGO RS, CHAMMAS R AND FIGUEIREDO LFPD. 2010. Aspectos fundamentais da experimentação animal - aplicações em cirurgia experimental. Rev Assoc Med Bras 56: 103-111.

DITTRICH R ET AL. 2015. Xenotransplantation of cryopreserved human ovarian tissue - a systematic review of MII oocyte maturation and discussion of it as a realistic option for restoring fertility after cancer treatment. Fertil Steril 103: 1557-1565.

DOEING DC, BOROWICZ JL AND CROCKETT ET. 2003. Gender dimorphism in differential peripheral blood leukocyte counts in mice using cardiac, tail, foot, and saphenous vein puncture methods. BMC Clin Pathol 3: 3 .

DOS SANTOS FA, PIMENTEL MML, TEIXEIRA ACG, COSMO ÍC, LIMA MA, DE BRITO PD, BEZERRA MB AND DE MACEDO MF. 2016. Follicular right shift: Xenografting queens' ovarian tissue into severe combined imunnodeficiency mice and its responses to exogenous gonadotropin. Theriogenology 86: 1811-1817.

FLORENCE MPB AND JEFFREY EM. 2010. Interpretation of hematology data in preclinical toxicological studies. In: Weiss DJ and Wardrop KJ (Eds), Schalm's Veterinary Hematology. Ames: Wiley-Blackwell, p. 79.

GONZÁLEZ FHD. 2009. Ferramentas de diagnóstico e monitoramento das doenças metabólicas. Ci Anim Bras 1: $1-22$.

GONZÁLEZ FHD, CARVALHO V, MÖLLER VA AND DUARTE FR. 2001. Perfil bioquímico sanguíneo de cães e gatos na cidade de Porto Alegre, Rio Grande do Sul, Brasil. Arq Fac Vet UFRGS 29: 1-6.

HOFF J. 2000. Methods of blood collection in the mouse. Lab Anim 29: 47-53.

HOGGATT J, HOGGATT AF, TATE TA, FORTMAN J AND PELUS LM. 2016. Bleeding the laboratory mouse: Not all methods are equal. Exp Hematol 44: 132-137.

HOROWITZ GL. 2008. Reference intervals: Practical aspects. EJIFCC 19: 2-95.

KIKUCHI K, NAKAI M, KASHIWAZAKI NAND KANEKO H. 2011. Xenografting of gonadal tissues into mice as a possible method for conservation and utilization of porcine genetic resources. Animal Sci J 82: 495-503.

KIM W, FLAMM SL, DI BISCEGLIE AM AND BODENHEIMER HC. 2008. Serum activity of alanine aminotransferase (ALT) as an indicator of health and disease. Hepatology 47: 1363-1370.

LANGBEEN A, VAN GINNEKEN C, FRANSEN E, BOSMANS E, LEROY JLMR AND BOLS PEJ. 2016.
Morphometrical analysis of preantral follicular survival of VEGF-treated bovine ovarian cortex tissue following xenotransplantation in an immune deficient mouse model. Anim Reprod Sci 168: 73-85.

MATIDA ET, ZANCANARO AE, RESTEL TI, GOMES VMW, BAZZANO T, MORI CMC AND TEIXEIRA MA. 2015. Determinação de parâmetros bioquímicos e hematológicos em camundongos (Mus musculus) do biotério central da UFMS. Rev Soc Bras Cienc Anim Lab 3: $30-35$.

MELO MGDD, DÓRIA GAA, SERAFINI MR AND ARAÚJO AADS. 2012. Valores de referência Hematológicos e Bioquímicos de Ratos (Rattus novergicus linhagem Wistar) provenientes do biotério central da Universidade Federal de Sergipe. Sci Plena 8: 1-6.

MENG Y, XU Z, WU F, CHEN W, XIE S AND LIU J. 2014. Sphingosine-1-phosphate suppresses cyclophosphamide induced follicle apoptosis in human fetal ovarian xenografts in nude mice. Fertil Steril 102: 871-877.

NOORANI L, STENZEL M, LIANG R, POURGHOLAMI MH AND MORRIS DL. 2015. Albumin nanoparticles increase the anticancer efficacy of albendazole in ovarian cancer xenograft model. J Nanobiotechnology 13: 25-36.

PIMENTEL MML, SANTOS FA, TEIXEIRA AC, IZZO RG, LIMA MA, MACEDO MF AND BEZERRA MB. 2017. Biochemical, thermographic, and follicular responses of murine models of hormone-treated bovine ovarian renal capsule xenografts. Pesqui Vet Bras 37: 425-431.

SANTOS EW, OLIVEIRA DCD, HASTREITER A, SILVA GBD, BELTRAN JSDO AND TSUJITA M. 2016. Hematological and biochemical reference values for C57BL/6, Swiss Webster and BALB/c mice. Braz J Vet Res Anim Sci 53: 138-145.

SPINELLI MO, DE GODOY CMSC, JUNQUEIRA MS, MOTTA MC AND BORTOLATTO J. 2012. Estudo comparativo dos valores hematológicos entre sexo e categorias sanitárias de camundongos C57BL/6 e BALB/c. Rev Soc Bras Cienc Anim Lab 1: 64-70.

SPINELLI MO, MOTTA MC, DA CRUZ RJ AND DE GODOY CMSC. 2014. Reference intervals for hematological parameters of animals bred and kept at the vivarium of the Faculty of Medicine of the State University of São Paulo. Acta Sci Health Sci 36: 1-4.

THRALL MA. 2007. Avaliação Laboratorial da Função Renal. In: Thrall MA (Ed), Hematologia e Bioquímica Clínica Veterinária. São Paulo: Roca, p. 289-328.

XIN G, QIN S, WANG S, WANG X, ZHANG Y AND WANG J. 2015. Sex hormone affects the severity of non-alcoholic steatohepatitis through the MyD88-dependent IL-6 signaling pathway. Exp Biol Med 240: 1279-1286.

XU Q, HIGGINS T AND CEMBROWSKI GS. 2015. Limiting the Testing of AST. Am J Clin Pathol 144: 423-426. 